\title{
Effects of copper glycine chelate on liver and faecal mineral concentrations, and blood parameters in broilers
}

\author{
Małgorzata Kwiecieńn ${ }^{1}$ Anna Winiarska-Mieczan², Jose Valverde Piedra³ , Barbara Bujanowicz-Haraś4, Agnieszka \\ Chałabis-Mazurek ${ }^{3}$
}

\begin{abstract}
${ }^{1}$ Institute of Animal Nutrition and Bromatology, University of Life Sciences, Akademicka 13, 20-950 Lublin, Poland
${ }^{2}$ Department of Bromatology and Food Physiology, University of Life Sciences, Akademicka 13, 20-950 Lublin, Poland

${ }^{3}$ Sub-Department of Toxicology and Environment Protection, University of Life Sciences, Akademicka 13, 20-950 Lublin, Poland

${ }^{4}$ Department of Management and Marketing, University of Life Sciences, Akademicka 13, 20-950 Lublin, Poland

email: malgorzatakwiecienar@wp.pl
\end{abstract}

\begin{abstract}
The aim of the study was to determine the influence of $\mathrm{Cu}$-glycine chelate on the chemical composition of the liver and blood parameters of broiler chickens. A total of 250 one-day-old Ross 308 male chicks were allotted into 5 groups with 5 replicates of 10 birds each. Rearing of birds lasted 42 days. In the experiment $\mathrm{Cu}$ was added to the premix in the form of $\mathrm{CuSO}_{4}(16 \mathrm{mg}, 8 \mathrm{mg} \mathrm{Cu})$, and in the form of $\mathrm{Cu}$ glycine chelate $(16 \mathrm{mg}, 8 \mathrm{mg}, 4 \mathrm{mg} \mathrm{Cu})$. The parameters in the chickens' blood remained within the range of physiological norms when lower levels of the analyzed elements were added. Adding lower levels of $\mathrm{Cu}\left(8 \mathrm{or} 4 \mathrm{mg} \cdot \mathrm{kg}^{-1}\right)$ in comparison with the recommended doses $\left(16 \mathrm{mg} \cdot \mathrm{kg}^{-1}\right)$ for broilers, in the form of highly assimilable organic sources, did not reduce the content of minerals $\mathrm{Cu}, \mathrm{Fe}$, and $\mathrm{Zn}$ in the chickens' liver, but reduced the faecal $\mathrm{Fe}, \mathrm{Cu}$ and $\mathrm{Zn}$ concentrations compared to $\mathrm{CuSO}_{4}$.
\end{abstract}

Key words: broiler chickens, copper, organic minerals, mineral excretion, blood indices

\section{Introduction}

The issue of optimising mineral nutrition for contemporary meat crossbreds needs continuous updating. This is a result of the rapidly progressing genetic improvement of chickens and simultaneous attempts at reducing environmental pollution by increasing doses of mineral components. The goals can be achieved thanks to more accurately balanced diets and improved accessibility of the components.

The requirement of minerals in contemporary meat crossbreds can be satisfied by including these components in feeding stuffs or using feed additives. As regards mineral components, among other additives, a phytase enzyme (PHY) is used to increase the availability of phosphorus (P) and other mineral components such as zinc ( $\mathrm{Zn}$ ), copper (Cu) and iron (Fe) (Świątkiewicz et al. 2001, Shelton et al. 2006). In addition to its mineral availability properties, PHY has been shown to decrease P excretion and reduce P-linked pollution in intensive poultry production (Waldroup et al. 2000).

The majority of previous studies revealed that organic compounds containing certain minerals in their structure are better utilized by animals. Such compounds include chelates, which are composed of ion metals bound with amino acids, mainly methionine and lysine (Banks et al. 2004, Predieri et al. 2005, Wang et al. 2007, Vieira 2008). It is believed that elements derived from mineral and organic compounds can be absorbed in an unchanged form by the intestinal mucous membrane through the amino acid transport system and are thus better assimilated by the body (Predieri et al. 2005, Wang et al. 2007, Vieira 2008). Recently, new additives have been produced in which methionine or lysine is replaced by glycine-an amino acid with a lower molecular mass. Chemically, these compounds are combinations of one to three glycine molecules with microelements such as $\mathrm{Cu}$ or Fe. Such a form seems to guarantee greater stability and better chemical and physical homogeneity. Glycine chelates can be even better assimilated and guarantee proper functioning of metabolic processes in the body, assessed, for example, on the basis of biochemical and haematological blood indices, than chelates with higher molecular mass (Männer et al. 2006, Feng 2007, 2009, Ettle et al. 2008). Feng et al. (2009), studying the effect of an Fe-glycine chelate additive, found an increased concentration of Fe in the hearts, livers, kidneys and spleens. In their previous studies Feng et al. (2007) demonstrated that along with increasing the amount of Fe supplied as Fe-glycine chelate, the level of haemoglobin, the haematocrit and blood Fe increased. In addition, Männer et al. (2006) determined that the stability and availability of intestinal chelates based on the smallest amino acid, i.e. glycine, is $25 \%$ higher than in older generation chelates based on lysine or methionine. 
Copper is an element with a very broad action spectrum, and thus it is involved in numerous metabolic transformations in the body and as a result it can significantly affect the health status of the animals (Reeves and DeMars 2004, Arredondo and Nunez 2005). This contributes to increasing the mitogenic activity in plasma and excretion of the growth hormone or peptides (Nys 2001). A supply of $100-250 \mathrm{mg} \cdot \mathrm{kg}^{-1}$ stimulates the growth of chicks (Nys 2001); however, such high doses increase its emission to the environment, which is not allowed by European Union regulations. Copper additive in feed has a beneficial effect on weight gain, the conversion of feed and modification of the bacterial microflora in the alimentary tract (Ruiz et al. 2000, Nys 2001, Makarski 2002). One possible mechanism by which $\mathrm{Cu}$ may benefit birds is shifting the gastrointestinal microbiota, thereby reducing the susceptibility of birds to disease, reducing intestinal lymphocyte recruitment and infiltration and thus increasing nutrient absorption (Arias and Koutsos 2006). Some researchers have demonstrated that supplementing broiler diets with high dietary Cu regulates intestinal microbiota through its bactericidal or bacteriostatic functions (Xia et al. 2004, Arias and Koutsos 2006). However, Aydin et al. (2010) reported that supplementing $250 \mathrm{ppm}$ of $\mathrm{Cu}$ from $\mathrm{Cu}$ proteinate had no significant effect on the number of pathogenic bacteria in the ileum or on the carcass.

However, due to the low level of absorption and retention of $\mathrm{Cu}$ in animals, it is extremely difficult to determine its assimilability from different products added to feeding stuffs. It is believed that the best method to determine the bio-availability of $\mathrm{Cu}$ is to directly measure its retention in birds' livers (Luo et al. 2005).

The study touches upon a very current issue, both on a national and international scale, regarding improvement in the availability of minerals in the diet of chicks and reduced emission of minerals. The results of previous studies (Kwiecień et al. 2015) indicate that the use of organic Fe did not decrease the production performance of chickens and their blood parameters, which could suggest that minerals administered in the form of glycine chelate are better assimilable in comparison to those supplied in an inorganic form even if their amount is lower than recommended. Therefore, a decision was made to verify whether the use of $\mathrm{Cu}$ in the form of glycine chelate administered in various amounts will not have a negative effect on the bodies of broiler chickens. The aim was to determine the influence of $\mathrm{Cu}$ in the form of glycine chelate ( $\mathrm{Cu}-\mathrm{Gly}$ ) on the liver and faecal mineral concentrations, biochemical and haematological blood parameters in Ross 308 chickens.

\section{Material and methods}

\section{Animals and experimental design}

All procedures used during the study were approved by the Local Ethics Committee for Animal Testing at the University of Life Sciences in Lublin, Poland (Resolution No. 37/2011 of 17 May 2011).

A total of 250 one-day-old Ross 308 male chicks were allotted into 5 groups with 5 replicates of 10 birds each. The birds were weighed individually at the beginning of the experiment. They were wing-banded and distributed randomly into 5 treatments of 250 chicks. They were kept under similar conditions of management throughout the experimental period. Artificial lighting was used to provide chicks with $24 \mathrm{~h}$ light during the whole experimental period. The initial brooding temperature was $33^{\circ} \mathrm{C}$ in the first week of age which was gradually reduced by $2{ }^{\circ} \mathrm{C}$ per week to $23^{\circ} \mathrm{C}$. Then it remained constant. Feed and water were provided ad libitum throughout the experimental period which lasted until the chicks were 42 days of age.

Feed mixtures were prepared on the basis of corn and wheat meals and soybean meal (Table 1). The birds were fed with a starter mixture (S) from the $1^{\text {st }}$ to the $21^{\text {st }}$ day of rearing, grower mixture $(G)$ from the $22^{\text {nd }}$ to the $35^{\text {th }}$ day and finisher mixture (F) from the $36^{\text {th }}$ to the $42^{\text {nd }}$ day of rearing. The $G$ and $F$ mixtures were administered in the form of pellets, while the $S$ mixture was in the form of a crumble. Following the instructions, basic $S, G$ and $F$ mixtures were prepared and, next, diversified with an addition of $\mathrm{Cu}$ in the form of sulphates and chelates. $1 \mathrm{~kg}$ of basic diet not supplemented with Cu contained S-6.10 mg, G-6.21 mg, and F-5.95 mg Cu. The premix was formulated to contain the required amount of trace elements either in inorganic $\left(\mathrm{CuSO}_{4} 5 \mathrm{H}_{2} \mathrm{O}, 25 \% \mathrm{Cu}\right)$ or organic combination (Cu-Gly, 16\% Cu and 37\% glycine).

The copper requirement of Ross 308 broilers is $16 \mathrm{mg} \mathrm{kg}^{-1}$ feed (Aviagen 2013). According to these recommendations, the content of $\mathrm{Cu}$ should be identical at each rearing stage, which was taken into account during the experiment. In the studies $\mathrm{Cu}$ was introduced into the mixtures at 2 levels of $\mathrm{CuSO}_{4}$ : at $100 \%$ of the requirement or at $50 \%$ and at 3 levels of Cu-Gly: at $100 \%$ of the requirement or at $50 \%$ or $25 \%$. 
M. Kwiecień et al. (2015) 24: 92-103

Table 1. Composition and nutritional value of basal diets

\begin{tabular}{|c|c|c|c|}
\hline \multirow[b]{2}{*}{ Ingredients (\%) } & \multicolumn{3}{|c|}{ Mixture } \\
\hline & $\begin{array}{c}\text { starter } \\
\text { (1-21 days) }\end{array}$ & $\begin{array}{c}\text { grower } \\
\text { (22-35 days) }\end{array}$ & $\begin{array}{c}\text { finisher } \\
\text { (36-42 days) }\end{array}$ \\
\hline Maize & 24.44 & 40.00 & 40.00 \\
\hline Wheat & 42.99 & 27.84 & 28.84 \\
\hline Soybean meal (46\% protein) & 25.00 & 24.97 & 22.87 \\
\hline Soybean oil & 2.50 & 3.69 & 3.98 \\
\hline Monocalcium phosphate & 0.90 & 0.90 & 0.81 \\
\hline Limestone & 1.40 & 1.13 & 1.09 \\
\hline Sodium bicarbonate & 0.08 & 0.08 & 0.08 \\
\hline $\mathrm{NaCl}$ & 0.29 & 0.25 & 0.26 \\
\hline Vitamin-mineral premix ${ }^{a}$ & $0.50^{b}$ & $0.50^{c}$ & $0.50^{d}$ \\
\hline Fat-protein concentrate $e^{e}$ & 1.00 & - & 1.00 \\
\hline DL-methionine 99\% & 0.30 & 0.23 & 0.23 \\
\hline L-lysine $\mathrm{HCl}$ & 0.42 & 0.28 & 0.27 \\
\hline L-threonine 99\% & 0.18 & 0.13 & 0.07 \\
\hline \multicolumn{4}{|l|}{ One kg feed mixtures contains } \\
\hline $\begin{array}{l}\text { Metabolizable energy } \\
\left(\mathrm{ME}, \mathrm{MJ} \mathrm{kg}^{-1}\right)\end{array}$ & 12.7 & 13.1 & 13.2 \\
\hline Available P, \% & 0.42 & 0.41 & 0.39 \\
\hline Total Ca/available P & 2.12 & 1.90 & 1.92 \\
\hline Crude protein, \% & 20.2 & 18.2 & 18.1 \\
\hline Crude fibre, \% & 3.06 & 2.99 & 2.99 \\
\hline Crude fat, \% & 4.66 & 6.08 & 6.43 \\
\hline Lysine, \% & 1.29 & 1.13 & 1.09 \\
\hline Methionine+cysteine, \% & 0.93 & 0.83 & 0.81 \\
\hline Total Ca, \% & 0.88 & 0.78 & 0.75 \\
\hline Total P, \% & 0.66 & 0.65 & 0.63 \\
\hline \multicolumn{4}{|l|}{$\mathrm{Cu}, \mathrm{mg}$} \\
\hline $16 \mathrm{mg} \mathrm{CuSO}$ & 22.10 & 22.21 & 21.95 \\
\hline $8 \mathrm{mg} \mathrm{CuSO}_{4}$ & 13.98 & 14.02 & 13.89 \\
\hline 16mg Cu-Gly & 21.98 & 22.15 & 22.02 \\
\hline 8mg Cu-Gly & 14.12 & 14.21 & 14.01 \\
\hline 4mg Cu-Gly & 10.10 & 10.21 & 9.98 \\
\hline $\mathrm{Fe}, \mathrm{mg}$ & 40.31 & 39.82 & 38.61 \\
\hline Zn, mg & 99.71 & 98.50 & 98.52 \\
\hline
\end{tabular}

${ }^{a}$ the premix was added Cu as CuSO4 in an amount of 16 or $8 \mathrm{mg} \mathrm{kg}^{-1}$, and Cu-Gly in an amount of 16,8 or $4 \mathrm{mg} \mathrm{kg}^{-1}$

${ }^{b}$ composition of the premix per kg of starter diet: Mn 100 mg, J 1 mg, Fe 40 mg, Zn 100 mg, Se 0.15 mg, vit. A 15000 UI, vit. D3 $5000 \mathrm{UI}$, vit. E $75 \mathrm{mg}$, vit. K3 $4 \mathrm{mg}$, vit. B1 $3 \mathrm{mg}$, vit. B2 $8 \mathrm{mg}$, vit. B6 5 mg, vit. B12 $0.016 \mathrm{mg}$, biotin $0.2 \mathrm{mg}$, folic acid $2 \mathrm{mg}$, nicotic acid $60 \mathrm{mg}$, pantothenic acid $18 \mathrm{mg}$, choline $1800 \mathrm{mg}$

c composition of the premix per kg of grower diet: Mn 100 mg, J 1 mg, Fe 40 mg, Zn 100 mg, Se 0.15 mg, vit. A 12000 UI, vit. D3 5000 UI, vit. E 50 mg, vit. K3 3 mg, vit. B1 2 mg, vit. B2 6 mg, vit. B6 4 mg, vit. B12 $0.016 \mu g$, biotin 0.2 mg, folic acid $1.75 \mathrm{mg}$, nicotic acid $60 \mathrm{mg}$, pantothenic acid $18 \mathrm{mg}$, choline $1600 \mathrm{mg}$

${ }^{d}$ composition of the premix per kg of finisher diet: Mn $100 \mathrm{mg}, \mathrm{J} 1 \mathrm{mg}$, Fe $40 \mathrm{mg}, \mathrm{Zn} 100 \mathrm{mg}$, Se $0.15 \mathrm{mg}$, vit. A $12000 \mathrm{UI}$, vit. D3 5000 Ul, vit. E 50 mg, vit. K3 2 mg, vit. B1 2 mg, vit. B2 5 mg, vit. B6 3 mg, vit. B12 $0.011 \mu$, biotin 0.05 mg, folic acid $1.5 \mathrm{mg}$, nicotic acid $35 \mathrm{mg}$, pantothenic acid $18 \mathrm{mg}$, choline $1600 \mathrm{mg}$

e $1 \mathrm{~kg}$ of fat-protein concentrate contain: $2 \%$ crude fat, $39 \%$ crude protein, $10,8 \mathrm{MJ}$ ME

Cu-Gly = copper glycine chelate

Three levels of chelate were used for the following reasons: firstly, the chicks' requirement of minerals as per the technical instructions of the breeder of Ross chicks ( $100 \%$ of the requirement) was covered; secondly the bioavailability of minerals declared by the manufacturer of chelates, i.e. ca. $50 \%$ (50\% of the requirement) was taken into account; and thirdly, scientific research information indicating that the levels of mineral components in poultry mixtures often exceed the requirement ( $25 \%$ of the requirement) was considered. 
In the experiment $\mathrm{Cu}$ was added to mixtures $\mathrm{S}, \mathrm{G}$ and $\mathrm{F}$ in an amount of 16 or $8 \mathrm{mg} \mathrm{kg}^{-1}$ in the form of $\mathrm{CuSO}_{4}$ (at $100 \%$ recommended levels for Ross broiler chicks or 50\%) - diet $16 \mathrm{mg}$ and $8 \mathrm{mg} \mathrm{CuSO}$; or in the form of Cu-Gly in an amount of 16, 8 or $4 \mathrm{mg} \mathrm{kg}^{-1}$ (at 100\%, 50\% and 25\% of the recommended levels for Ross broiler chicks) - diets $16 \mathrm{mg}$ Cu-Gly, $8 \mathrm{mg}$ Cu-Gly, $4 \mathrm{mg}$ Cu-Gly.

The basal diets were formulated using NRC (1994) guidelines. According to these standards and industry-specific nutrition recommendations for Ross 308 broiler chicks (Aviagen 2013), the requirement of Cu is covered regardless of the amount supplied by typical feed components. The control group was a group receiving additional $\mathrm{Cu}$ in the form of $\mathrm{CuSO}_{4} 5 \mathrm{H}_{2} \mathrm{O}$, corresponding to $100 \%$ of the requirement. With regard to good assimilability, as a standard, the sources of microelements used in the production of feed mixtures include well soluble inorganic forms. Therefore, the source of $\mathrm{Cu}$ in the experiment was $\mathrm{CuSO}_{4} 5 \mathrm{H}_{2} \mathrm{O}$. The experiment involved the use of GLYSTAR FORTE chelate (2:1 glycine-metal ratio) made by ARKOP Sp. z.o.o.

\section{Experimental measurements}

All feathers were carefully removed from the faeces by hand. Whole-stool samples were collected on the last, i.e. $42^{\text {nd }}$, day of the experiment, from 10 birds from each group. Then the faeces were mixed within respective groups (collective sample), placed in sterile plastic containers and frozen at a temp. of $-20^{\circ} \mathrm{C}$ for future chemical analysis. Prior to the analyses the material was thawed at room temperature. Afterwards, the samples were dried at a temp. of $60^{\circ} \mathrm{C}$ over $24 \mathrm{~h}$ and ground in an electrical grinding mill. A $50 \mathrm{~g}$ representative sample of the material prepared as described above was collected and placed in a sterile plastic container at room temperature. After faecal collection, birds were returned to their original pens.

The birds were slaughtered after $10 \mathrm{~h}$ of starvation during which they had unlimited access to water (EC 2009). All the animals were clinically healthy. On the last day of rearing, the birds were weighed and 10 from each group with body weight closest to the average weight in the group were selected for slaughter. After slaughter, a simplified dissection analysis (Ziołecki and Doruchowski 1989) was performed during which the livers were weighed, packed into labelled plastic bags and frozen (at a temperature of $-25^{\circ} \mathrm{C}$ ) until the time of analysis. Blood samples (10 samples per treatment) for analysis were taken from the wing vein (vena cutanea ulnaris) in the morning of the slaughter day. Blood for haematology tests was sampled into $2 \mathrm{ml}$ Vacutest tubes containing $\mathrm{K}_{3}$ EDTA anticoagulant. The material for biochemical tests was blood sampled into $6 \mathrm{ml}$ Vacutest tubes containing lithium heparin. During transport blood was stored at a temperature of 2 to $8^{\circ} \mathrm{C}$.

\section{Chemical analysis \\ Liver}

The livers were used to determine the content of dry matter, crude protein, crude fat and crude ash with the use of AOAC (2000). Samples of liver were dried at $100{ }^{\circ} \mathrm{C}$ for $24 \mathrm{~h}$ and ashed for $10 \mathrm{~h}$ at $550{ }^{\circ} \mathrm{C}$. The ashed samples were dissolved in a nitric acid-perchloric acid mixture (1:1) and diluted with deionised water for mineral analysis. The contents of $\mathrm{Fe}, \mathrm{Cu}, \mathrm{Zn}$ and $\mathrm{Ca}$ were measured using flame atomic absorption spectrophotometry (Unicam 939/959AA-6300, Shimadzu Corp., Tokyo, Japan).

\section{Feed and faeces}

The contents of dry matter, crude ash, crude protein, crude fat and crude fibre in feed samples were determined with standard AOAC (2000). The thawed faeces were thoroughly mixed, weighed, and dried for $24 \mathrm{~h}\left(65^{\circ} \mathrm{C}\right)$. The $\mathrm{Cu}, \mathrm{Fe}, \mathrm{Zn}$ and $\mathrm{Ca}$ content in feed and $\mathrm{Cu}, \mathrm{Fe}$ and $\mathrm{Zn}$ in faecal samples was determined using the AAS flame technique in a Unicam 939 (AA Spectrometer Unicam, Shimadzu Corp., Tokyo, Japan) apparatus, after ashing at $550{ }^{\circ} \mathrm{C}$, according to the methods of AOAC (2000). Total P content in the feed was determined colorimetrically (PN-76/R-64781, 1976) with a Helios Alpha UV-VIS apparatus (Spectronic Unicam, Leeds, United Kingdom).

The amino acid composition in feed was determined by ion-exchange chromatography using an INGOS AAA 400 amino acid analyser (Ingos Ltd., Czech Republic) with post-column ninhydrin derivatization and spectrophotometric detection according to the standard manufacturer's procedure and MCMiAŻ/PB-03 test procedure. 
The samples were hydrolyzed in an aqueous solution ( $6 \mathrm{~N} \mathrm{HCl}+0.5 \%$ phenol at a temperature of $110^{\circ} \mathrm{C}$ for $\left.24 \mathrm{~h}\right)$. Sulphur amino acids (cysteine and methionine) were determined in a separate analysis as oxidised derivatives (cysteic acid and methionine sulfone) resulting from oxidation with performic acid and then released from proteins during acid hydrolysis. Assimilable lysine was determined based on the difference between total lysine and the so-called residual lysine which did not react with DNFB (dinitrofluorobenzene). Following this reaction, the tested samples were again subjected to acid hydrolysis (Žilic et al. 2006).

\section{Blood}

Complete blood analysis was performed within three hours of collection using an ABACUS Junior Vet haematology analyser (Diatron, Vienna, Austria). The complete blood count determined the haematocrit value (Ht), concentration of haemoglobin $(\mathrm{Hb})$, red blood cell $(\mathrm{RBC})$ and white blood cell count (WBC).

Plasma for the analysis of biochemical indicators was obtained by centrifugation of complete blood at $3000 \mathrm{rpm}$ over 15 minutes in a laboratory centrifuge (MPW-350R, MPW Medical Instruments, Warsaw, Poland) at a temperature of $4^{\circ} \mathrm{C}$. The plasma was analysed within four hours of collection; zinc, calcium, copper, iron, total protein, glucose levels, uric acid, triacylglycerols (TG), total cholesterol and high-density lipoprotein (HDL) were determined along with the activity of the following enzymes: alanine transaminase (ALT), aspartate transaminase (AST), alkaline phosphatase (ALP) and lactate dehydrogenase (LDH). The above-mentioned components of blood plasma were analysed by colorimetric methods, described in the manual, using BioMaxima reagent sets (Lublin, Poland) in a Metrolab 2300GL random-access biochemical analyzer (Metrolab SA, Buenos Aires, Argentina). Low-density cholesterol fraction (LDL) was calculated from the formula designed by Friedewald et al. (1972):

$$
L D L\left(\mathrm{mmol}^{-1}\right)=\text { cholesterol }-H D L-(T G / 2.2)
$$

\section{Statistical analysis}

The results of laboratory and manufacturing tests were statistically analyzed, using the Statistica software ver. 10 (Statsoft Inc., Tulsa, USA). The elements calculated were measures of location (arithmetic mean) and absolute measures (SEM), and single-factor analysis of variance. Significant statistical differences were set at the level of $p<0.05$ and $p<0.01$. The significance of the differences between mean values in particular diets was assessed using Duncan's multiple range test.

\section{Results}

Introducing organic $\mathrm{Cu}$ into broiler mixes at levels lower than those recommended did not deteriorate the effectiveness of chicken fattening and mortality of chicks compared to inorganic forms where microelements were sourced from $\mathrm{CuSO}_{4}$ (Table 2).

An addition of $\mathrm{Cu}$ in the form of $\mathrm{CuSO}_{4}$ satisfying up to $50 \%$ of the requirement $p<0.01$ increased the content of crude protein in the chickens' livers, compared to the remaining groups (Table 2). No influence of Cu added to the mixtures on the content of other basic components was demonstrated.

The lowest share of $\mathrm{Cu}\left(4.79 \mathrm{mg} \cdot \mathrm{kg}^{-1}\right)$ was observed in the livers of the chickens obtaining an addition of $\mathrm{Cu}$ in the form of $\mathrm{CuSO}_{4}$ corresponding to $50 \%$ of the requirement, while the lowest content of $\mathrm{Zn}$ and Ca was recorded in the group of birds fed with $\mathrm{CuSO}_{4}$ corresponding to 100 and $50 \%$ of the requirement.

The addition of $\mathrm{Cu}$ in the form of Cu-Gly had a significant effect on reducing the amount of Fe, $\mathrm{Cu}$ and $\mathrm{Zn}$ excreted with chicken droppings (Table 2); on average it reduced the amount of Fe excreted with droppings by ca. $8 \%$ compared to diets with the addition of $\mathrm{CuSO}_{4}$.

Also, it decreased the amount of excreted $\mathrm{Cu}$ by ca. $5 \%$ compared to the recommended dose of $16 \mathrm{mg} \mathrm{CuSO}_{4}$. An increased excretion of $\mathrm{Zn}$ with droppings was observed after the introduction of $\mathrm{CuSO}_{4}$ compared to Cu-Gly. 
Table 2. Effects of copper glycine chelate on final body weight, mortality, liver weights and chemical composition of liver and on mineral contents in the faeces of chickens (mean value)

\begin{tabular}{|c|c|c|c|c|c|c|c|}
\hline Cu source & $\mathrm{CuSO}_{4}$ & & Cu-Gly & & & & \\
\hline $\mathrm{Cu}$ addition $\left(\mathrm{mg} \cdot \mathrm{kg}^{-1}\right)$ & 16 & 8 & 16 & 8 & 4 & SEM & $p$ value \\
\hline Final BW (g) & 2430 & 2324 & 2485 & 2479 & 2359 & 18.21 & 0.244 \\
\hline $\begin{array}{l}\text { Share of liver in the body } \\
\text { weight (\%) }\end{array}$ & 1.72 & 1.87 & 1.73 & 1.64 & 1.76 & 0.259 & 0.238 \\
\hline Mortality (\%) & 2.00 & 2.00 & 0.00 & 0.00 & 2.00 & 6.380 & 0.234 \\
\hline \multicolumn{8}{|c|}{ Chemical composition of liver (\%) } \\
\hline Dry matter & 23.2 & 22.9 & 22.6 & 22.9 & 22.8 & 0.130 & 0.683 \\
\hline Crude ash & 1.18 & 1.25 & 1.19 & 1.21 & 1.21 & 0.011 & 0.317 \\
\hline Crude protein & $17.4^{\mathrm{B}}$ & $18.3^{\mathrm{A}}$ & $16.9^{\mathrm{B}}$ & $17.3^{\mathrm{B}}$ & $16.9^{\mathrm{B}}$ & 0.124 & $<0.001$ \\
\hline Crude fat & 4.83 & 4.06 & 4.21 & 4.10 & 4.41 & 0.079 & 0.645 \\
\hline \multicolumn{8}{|c|}{ Mineral composition of liver $\left(\mathrm{mg} \cdot \mathrm{kg}^{-1}\right)$} \\
\hline $\mathrm{Cu}$ & $6.00^{\mathrm{A}}$ & $4.79^{\mathrm{B}}$ & $5.59^{\mathrm{A}}$ & $5.50^{\mathrm{A}}$ & $5.62^{\mathrm{A}}$ & 0.078 & 0.001 \\
\hline $\mathrm{Fe}$ & 84.4 & 84.1 & 92.8 & 90.6 & 90.0 & 1.201 & 0.092 \\
\hline $\mathrm{Zn}$ & $34.1^{\mathrm{B}}$ & $31.4^{\mathrm{B}}$ & $56.1^{\mathrm{A}}$ & $53.5^{\mathrm{A}}$ & $54.6^{\mathrm{A}}$ & 1.458 & $<0.001$ \\
\hline $\mathrm{Ca}$ & $20.5^{\mathrm{c}}$ & $18.2^{\mathrm{C}}$ & $25.6^{\mathrm{B}}$ & $30.2^{\mathrm{A}}$ & $25.7^{\mathrm{B}}$ & 0.001 & $<0.001$ \\
\hline \multicolumn{8}{|c|}{ Mineral contents in faecal $\left(\mathrm{mg} \cdot \mathrm{kg}^{-1}\right)$} \\
\hline $\mathrm{Fe}$ & $132.7^{\mathrm{a}}$ & $131.6^{\mathrm{a}}$ & $122.3^{\mathrm{b}}$ & $120.9^{b}$ & $121.8^{\mathrm{b}}$ & 2.585 & 0.022 \\
\hline $\mathrm{Cu}$ & $24.6^{\mathrm{a}}$ & $24.2^{\mathrm{ab}}$ & $23.4^{\mathrm{b}}$ & $23.4^{\mathrm{b}}$ & $23.6^{\mathrm{b}}$ & 0.251 & 0.030 \\
\hline $\mathrm{Zn}$ & $177.1^{\mathrm{A}}$ & $181.3^{\mathrm{A}}$ & $159.3^{B}$ & $158.9^{\mathrm{B}}$ & $159.4^{\mathrm{B}}$ & 4.949 & 0.006 \\
\hline
\end{tabular}

A, B - means with different superscripts in lines differ at $p<0.01$

a, b - means with different superscripts in lines differ at $p<0.05$

$\mathrm{BW}=$ body weight

Cu-Gly = copper glycine chelate

$\mathrm{EEI}=$ European Efficiency Index

$\mathrm{SEM}=$ standard error of the means

The addition of $\mathrm{Cu}$-Gly resulted in an increased content of total protein and $\mathrm{Cu}$ and a lower content of glucose, uric acid, $\mathrm{Fe}$ and $\mathrm{Ca}$ in the chickens' blood, with reference to $\mathrm{Cu}$ in an inorganic form (Table 3). Introducing an addition of $\mathrm{Cu}$, covering up to $100 \%$ of the requirement, in the form of $\mathrm{Cu}-\mathrm{Gly}$, significantly reduced the share of $\mathrm{Zn}$ in blood compared to the remaining experimental groups. The highest concentration of Fe $\left(22.4 \mu \mathrm{mol} \cdot \cdot^{-1}\right)$ in blood was noted in the group of chickens administered $8 \mathrm{mg} \cdot \mathrm{kg}^{-1}$ of $\mathrm{Cu}$ in the form of $\mathrm{CuSO}_{4}$, while the lowest content of this element $\left(20.1 \mu \mathrm{mol} \cdot \cdot^{-1}\right)$ was observed in chickens receiving Cu-Gly at the level of $8 \mathrm{mg} \cdot \mathrm{kg}^{-1}\left(\mathrm{Table}^{3}\right)$.

The concentration of total cholesterol, TG and LDL fraction, irrespective of the amount of Cu in the mixtures, was significantly lower in the groups of chickens receiving organic copper additive (Table 3). HDL fraction was also found to have increased with the addition of Cu-Gly at the level of $100 \%, 50 \%$ and $25 \%$ of the requirement $(p<0.01)$ compared to diets obtaining a mixture with $\mathrm{Cu}$ added in an inorganic form.

The activity of enzymes in the plasma of broiler chickens using organic and inorganic forms of $\mathrm{Cu}$ is presented in Table 3. An addition of $\mathrm{Cu}$ in the form of $\mathrm{CuSO}_{4}$, corresponding to up to $50 \%$ of the requirement for this element, resulted in reducing the activity of AST in comparison to the other groups $(p<0.01)$. Moreover, a significantly higher activity of ALT was observed in groups administered Cu-Gly chelate compared with its activity in the plasma of chickens receiving feed with inorganic $\mathrm{Cu}$ additive. The highest $\mathrm{LDH}$ activity was recorded in the plasma of chickens fed $\mathrm{Cu}$ additive in the form of Cu-Gly amounting to $25 \%$. 
AGRICULTURAL AND FOOD SCIENCE

M. Kwiecień et al. (2015) 24: 92-103

Table 3. Effects of copper glycine chelate on some biochemical parameters in chicken blood (mean value)

\begin{tabular}{|c|c|c|c|c|c|c|c|}
\hline Cu source & $\mathrm{CuSO}_{4}$ & & Cu-Gly & & & & \\
\hline $\mathrm{Cu}$ addition $\left(\mathrm{mg} \cdot \mathrm{kg}^{-1}\right)$ & 16 & 8 & 16 & 8 & 4 & SEM & $p$ value \\
\hline Glucose $\left(\left.\mathrm{mmo} \cdot\right|^{-1}\right)$ & $9.84^{\mathrm{A}}$ & $9.94^{\mathrm{A}}$ & $8.82^{\mathrm{B}}$ & $8.98^{\mathrm{B}}$ & $8.86^{\mathrm{B}}$ & 0.098 & $<0.001$ \\
\hline Total protein $\left(\left.g \cdot\right|^{-1}\right)$ & $28.6^{\mathrm{B}}$ & $27.9^{\mathrm{B}}$ & $30.3^{\mathrm{A}}$ & $30.5^{\mathrm{A}}$ & $31.1^{\mathrm{A}}$ & 0.244 & $<0.001$ \\
\hline Uric acid $\left(\mathrm{mmol} \cdot \mathrm{l}^{-1}\right)$ & $0.35^{A}$ & $0.37^{A}$ & $0.24^{\mathrm{B}}$ & $0.26^{\mathrm{B}}$ & $0.27^{\mathrm{B}}$ & 0.010 & $<0.001$ \\
\hline Total cholesterol $\left(\mathrm{mmol} \cdot \cdot^{-1}\right)$ & $3.37^{\mathrm{A}}$ & $3.33^{\mathrm{A}}$ & $2.70^{\mathrm{B}}$ & $2.73^{\mathrm{B}}$ & $2.65^{\mathrm{B}}$ & 0.068 & $<0.001$ \\
\hline HDL-cholesterol $\left(\left.\mathrm{mmol} \cdot\right|^{-1}\right)$ & $2.22^{\mathrm{B}}$ & $2.25^{\mathrm{B}}$ & $2.65^{A}$ & $2.66^{\mathrm{A}}$ & $2.70^{\mathrm{A}}$ & 0.046 & $<0.001$ \\
\hline LDL-cholesterol $\left(\left.\mathrm{mmol} \cdot\right|^{-1}\right)$ & $0.79^{\mathrm{a}}$ & $0.79^{\mathrm{a}}$ & $0.60^{\mathrm{b}}$ & $0.61^{\mathrm{b}}$ & $0.59^{\mathrm{b}}$ & 0.027 & 0.024 \\
\hline $\mathrm{TG}\left(\mathrm{mmol} \cdot \mathrm{I}^{-1}\right)$ & $0.18^{\mathrm{A}}$ & $0,18^{A}$ & $0.14^{\mathrm{B}}$ & $0.15^{\mathrm{B}}$ & $0.15^{\mathrm{B}}$ & 0.004 & $<0.001$ \\
\hline $\operatorname{ALP}\left(\left.U \cdot\right|^{-1}\right)$ & 998 & 1099 & 1056 & 1040 & 1163 & 39.80 & 0.760 \\
\hline $\operatorname{ALT}\left(\left.U \cdot\right|^{-1}\right)$ & $11.3^{\mathrm{B}}$ & $11.1^{\mathrm{B}}$ & $12.6^{\mathrm{A}}$ & $12.5^{\mathrm{A}}$ & $12.6^{\mathrm{A}}$ & 0.168 & 0.001 \\
\hline AST $\left(\left.U \cdot\right|^{-1}\right)$ & $261^{A}$ & $236^{B}$ & $279^{A}$ & $277^{A}$ & $273^{A}$ & 3.423 & $<0.001$ \\
\hline $\operatorname{LDH}\left(\left.U \cdot\right|^{-1}\right)$ & $1216^{\mathrm{B}}$ & $1196^{\mathrm{B}}$ & $1208^{B}$ & $1215^{\mathrm{B}}$ & $1360^{\mathrm{A}}$ & 12.92 & $<0.001$ \\
\hline $\mathrm{Cu}\left(\left.\mu \mathrm{mol} \cdot\right|^{-1}\right)$ & $1.33^{\mathrm{B}}$ & $1.46^{\mathrm{B}}$ & $2.04^{\mathrm{A}}$ & $2.27^{\mathrm{A}}$ & $2.04^{\mathrm{A}}$ & 0.057 & $<0.001$ \\
\hline $\mathrm{Fe}\left(\mu \mathrm{mol} \cdot \mathrm{I}^{-1}\right)$ & $21.9^{A}$ & $22.1^{\mathrm{A}}$ & $20.4^{\mathrm{B}}$ & $20.1^{\mathrm{B}}$ & $20.5^{\mathrm{B}}$ & 0.535 & $<0.001$ \\
\hline $\mathrm{Zn}\left(\left.\mu \mathrm{mol} \cdot\right|^{-1}\right)$ & $28.5^{\mathrm{b}}$ & $29.1^{\mathrm{a}}$ & $26.4^{b}$ & $29.1^{\mathrm{a}}$ & $28.4^{\mathrm{a}}$ & 0.301 & 0.017 \\
\hline $\mathrm{Ca}\left(\mathrm{mmol} \cdot \mathrm{l}^{-1}\right)$ & $1.99^{\mathrm{A}}$ & $2.01^{\mathrm{A}}$ & $1.73^{\mathrm{B}}$ & $1.72^{\mathrm{B}}$ & $1.70^{\mathrm{B}}$ & 0.026 & $<0.001$ \\
\hline \multicolumn{8}{|l|}{$\begin{array}{l}\text { A, B - means with different sup } \\
\text { a, b - means with different supe } \\
\text { Cu-Gly = copper glycine chelat } \\
\text { SEM = standard error of the m } \\
\text { TG = triacylglycerols } \\
\text { ALP = alkaline phosphatase } \\
\text { ALT = alanine transaminase } \\
\text { AST = aspartate transaminase } \\
\text { LDH = lactate dehydrogenase }\end{array}$} \\
\hline
\end{tabular}

The highest WBC count was revealed with the use of feed with an addition of Cu-Gly covering $25 \%$ of the requirement. On the other hand, an addition of $\mathrm{Cu}$ in the form of $\mathrm{CuSO}_{4}$, covering $50 \%$ of the requirement, significantly reduced the WBC count compared to chickens receiving feed with an addition of $8 \mathrm{mg}$ and $4 \mathrm{mg} \mathrm{Cu}$ in the form $\mathrm{Cu}$-Gly (Table 4). The highest RBC count was observed with the addition of $16 \mathrm{mg} \mathrm{CuSO}_{4}$ which was significantly higher than the value of this index in the remaining groups. Lower values of $\mathrm{Ht}$ were noted with the use of the inorganic form added at the level satisfying $100 \%$ and $50 \%$ of the $\mathrm{Cu}$ requirement. An addition of $\mathrm{Cu}$ in the form of $\mathrm{Cu}-\mathrm{Gly}$, irrespective of the level applied, resulted in a significant increase in the $\mathrm{Ht}$ value.

Table 4. Effects of copper glycine chelate on some haematological indices of chicken blood (mean value)

\begin{tabular}{|c|c|c|c|c|c|c|c|}
\hline Cu source & $\mathrm{CuSO}_{4}$ & & Cu-Gly & & & & \\
\hline $\mathrm{Cu}$ addition $\left(\mathrm{mg} \cdot \mathrm{kg}^{-1}\right)$ & 16 & 8 & 16 & 8 & 4 & SEM & $p$ value \\
\hline WBC $\left(\left.10^{9} \cdot\right|^{-1}\right)$ & $28.8^{c}$ & $29.2^{\mathrm{ab}}$ & $29.9^{\mathrm{abc}}$ & $30.8^{\mathrm{abc}}$ & $30.9^{a}$ & 0.291 & 0.027 \\
\hline $\operatorname{RBC}\left(\left.10^{12} \cdot\right|^{-1}\right)$ & $1.91^{\mathrm{A}}$ & $1.75^{\mathrm{B}}$ & $1.74^{\mathrm{B}}$ & $1.71^{\mathrm{B}}$ & $1.77^{\mathrm{B}}$ & 0.018 & 0.001 \\
\hline $\mathrm{Hb}\left(\mathrm{mmol} \cdot \mathrm{l}^{-1}\right)$ & 8.13 & 8.00 & 8.28 & 8.54 & 8.56 & 0.075 & 0.180 \\
\hline $\mathrm{Ht}\left(|\cdot|^{-1}\right)$ & $0.25^{\mathrm{B}}$ & $0.25^{\mathrm{B}}$ & $0.26^{A}$ & $0.25^{\mathrm{B}}$ & $0.27^{A}$ & 0.002 & 0.003 \\
\hline
\end{tabular}

A, B - means with different superscripts in lines differ at $p<0.01$

a, b c - means with different superscripts in lines differ at $p<0.05$

Cu-Gly = copper glycine chelate

SEM = standard error of the means

$\mathrm{WBC}=$ white blood cell

$\mathrm{RBC}=$ red blood cell

$\mathrm{Hb}=$ haemoglobin

$\mathrm{Ht}=$ haematocrit 


\section{Discussion \\ Chemical composition of liver and faeces}

The earlier results of own studies (Kwiecień et al. 2014, Winiarska and Kwiecień 2015) form evidence of the beneficial effect of Gly-Cu additive in feed mixtures on the growth and development of broiler chickens. Throughout the rearing period the replacement of $\mathrm{CuSO}_{4}$ with $\mathrm{Cu}-\mathrm{Gly}$ did not significantly alter the weight of chickens. The addition of Gly-Cu chelate in the chicken diets did not change the feed to gain ratio, dressing percentage and content of breast and thigh meat in the carcass.

The levels of $\mathrm{Cu}$ applied in the experiment did not lead to significant changes in the content of the basic components in the birds' livers. Only with an addition of $\mathrm{Cu}$ in organic form, was a significant reduction in the content of crude protein noted in the birds' livers. Similarly, in studies published by Makarski et al. (2006) a significant decrease (of $11.8 \%$ ) in total protein was recorded in the livers of birds obtaining an addition of Cu-Lys chelate amounting to $10 \mathrm{mg} \cdot \mathrm{kg}^{-1}$.

The source of copper significantly affects Cu concentration in the liver of broiler chickens (Wang et al. 2007). In the author's own studies, the lowest concentration of $\mathrm{Cu}$ in the chickens' livers was noted with the addition of $\mathrm{Cu}$, limited to $50 \%$, in the form of $\mathrm{CuSO}_{4}$. Makarski (2002) observed an increase in the content of $\mathrm{Cu}$ in the liver of turkeys with the addition of $\mathrm{Cu}$ in the form of a chelate amounting to $30 \mathrm{mg} \cdot \mathrm{dm}^{-3}$. Also, later studies by Makarski et al. (2009b) suggest that adding $50 \mathrm{mg} \cdot \mathrm{dm}^{-3}$ of Cu chelate to water resulted in a statistically significant increase in $\mathrm{Cu}$ concentration and a slightly higher concentration of $\mathrm{Ca}, \mathrm{Zn}$ and Fe in the birds' livers. Güçlü et al. (2008) recorded an increased level of $\mathrm{Cu}$ in the liver when the diet was supplemented with $\mathrm{Cu}$ protein amounting to 300 and $450 \mathrm{mg} \cdot \mathrm{kg}^{-1}$. Conversely, Pierce et al. (2005) observed a higher content of $\mathrm{Cu}$ in the birds' livers when $250 \mathrm{ppm}$ of $\mathrm{Cu}$ was used in the form of a sulphate. On the other hand, Bao et al. (2007) did not observe any significant differences in $\mathrm{Cu}$ concentration in the livers of chickens administered low levels of $\mathrm{Cu}$ in an organic form $\left(2 \mathrm{mg} \mathrm{kg}^{-1}\right)$, medium $\left(4 \mathrm{mg} \mathrm{kg}^{-1}\right)$, high $\left(8 \mathrm{mg} \mathrm{kg}^{-1}\right)$, and in an inorganic form. It is believed that better assimilability of metals from organic forms than from inorganic forms in birds depends on how easily these compounds are converted into adequate organic combinations which are biologically active.

The use of Cu-Gly in the mixture, regardless of its level, significantly decreased the excretion of Fe, $\mathrm{Zn}$ and Cu with droppings into the environment compared to the recommended dose of $\mathrm{CuSO}_{4}$. The results of literature-based studies indicate that decreasing $\mathrm{Cu}$ in the diet to the level of nutritional requirements is an effective method of reducing the excretion of $\mathrm{Cu}$ with droppings. The results of studies involving chickens carried out by Nollet et al. (2005) indicate that the replacement of the mineral form of added copper with a bioplex at the same level (Cu $12.5 \mathrm{ppm}$ ) made it possible to reduce the excretion of $\mathrm{Cu}$ in birds. Using $12 \mathrm{ppm} \mathrm{Cu}$ in the form of sulphate in the control mixture and $2.5 \mathrm{ppm}$ Cu bioplex in the experimental mixture, it was found that the excretion of $\mathrm{Cu}$ with droppings was lower by $55 \%$ with reference to sulphates (Nollet et al. 2007). Nollet et al. (2008) supplementing $\mathrm{Cu}$ at 5 levels in the form of two- and three-peptide bioplex found that the smallest loss of Cu was recorded at the lowest doses (2.5 ppm and 5 ppm). Dozier et al. (2003) administered from 4 to $12 \mathrm{mg} \mathrm{Cu}$, both in inorganic form (sulphates), organic form (amino acid chelate) and as a mineral-organic combination. The results suggest that the supply of Cu decreased from 12 to $4 \mathrm{mg}$ reduced the excretion of this element into the environment by $35 \%$. It seems that improved assimilability of metals from organic than inorganic forms is determined by the ease of conversion of such compounds by animals into adequate biologically active organic combinations.

\section{Biochemical indicators of blood}

In the experiment the effect of using organic forms of $\mathrm{Cu}$ on the level of glucose, total protein and uric acid was observed (Ganong 2005). Changes in the level of glucose in blood reflect the changes of sugar in the body. The use of Cu-Gly resulted in lowering the level of glucose in blood, which suggests that glucose metabolism can be regulated with the help of Cu chelate compounds. The author's own studies confirmed that Cu has "insulin-like" properties because it lowers the level of glucose in the plasma, thus stimulating the bio-synthesis of protein. Makarski (2002) in his studies involving turkeys observed a decrease in the level of glucose in the birds' blood after adding lysine chelate to drinking water at the amount of 10, 20 and $30 \mathrm{mg} \mathrm{Cu} \cdot \mathrm{l}^{-1}$. On the other hand, the content of total protein with partial and/or total replacement of $\mathrm{CuSO}_{4}$ with its organic equivalent was significantly higher. The increase in the content of protein may suggest accelerated bio-synthesis of issue protein or decelerated catabolic processes of proteins. However, with no data available in the literature, interpreting the obtained results is quite problematic. 
Additionally, the obtained results suggest that increased doses of Gly-Cu in feed result in reducing the level of uric acid in blood. The observed differences were confirmed by statistics $(p<0.01)$. The reduction in the level of uric acid, suggesting a decrease in the catabolism of amino acids in the process of deamination in the case of increased use of amino acids from the so-called pool of free amino acids in blood, can testify to the influence of $\mathrm{Cu}$ on the increased utilisation of amino acids in protein synthesis.

After the $42^{\text {nd }}$ day of rearing blood samples were taken in order to determine the content of $\mathrm{Cu}, \mathrm{Fe}, \mathrm{Zn}$ and $\mathrm{Ca}$. The concentration of $\mathrm{Cu}$ was significantly higher in groups of chickens receiving $\mathrm{Cu}$ in an organic form in comparison with groups fed mixtures with $\mathrm{CuSO}_{4}$. This may suggest better assimilability of copper from organic forms. The use of $\mathrm{Cu}\left(10 \mathrm{mg} \cdot \mathrm{kg}^{-1}\right)$ in an organic form in studies by Dobrzański et al. (2008) resulted in a significant increase in the concentration of $\mathrm{Cu}$ in hens' blood. An increase in the concentration of Fe and $\mathrm{Cu}$ and a lower concentration of glucose in blood were recorded in the studies by Makarski et al. (2002) with an addition of $\mathrm{Cu}$ in the form of Cu-lysine chelate and Cu-methionine. Aksu et al. (2010) noted a drop in the level of Cu between chickens fed $2 / 3$ of the recommended dose $\left(26 \mathrm{mg} \cdot \mathrm{kg}^{-1} \mathrm{Zn}, 5 \mathrm{mg} \cdot \mathrm{kg}^{-1} \mathrm{Cu}, 40 \mathrm{mg} \cdot \mathrm{kg}^{-1} \mathrm{Mn}\right.$ ) and those with full requirement satisfied (40 mg $\mathrm{kg}^{-1} \mathrm{Zn}, 8 \mathrm{mg} \cdot \mathrm{kg}^{-1} \mathrm{Cu}, 60 \mathrm{mg} \cdot \mathrm{kg}^{-1} \mathrm{Mn}$ ) for elements in the form of organic compounds, which could be caused by an interaction between $\mathrm{Zn}$ and $\mathrm{Cu}$. Different results were obtained by Dmoch and Polonis (2007) who did not observe any influence of the form of $\mathrm{Cu}$ on its content while using $\mathrm{Cu}$-lysine chelate; however, they noted a slight decrease in the content of Ca, P, Fe and Zn in the chickens' plasma. Similarly, Mondal et al. (2007) noted that the source of $\mathrm{Cu}$ in the diet did not affect the balance of the main minerals or their concentration in the plasma.

Following partial or complete replacement of inorganic $\mathrm{Cu}$ in the feed with its organic equivalent, the level of $\mathrm{Ca}$ in blood was significantly reduced. It seems that the influence of $\mathrm{Cu}$ on the concentration of $\mathrm{Ca}$ in blood may occur in the liver through the inhibition of 25-hydroxylase, which catalyses production of 25-hydroxycholecalciferol responsible for absorbing $\mathrm{Ca}$ in the upper section of the small intestine, by active transportation. $1.25-(\mathrm{OH})_{2} \mathrm{D}_{3}$ models the synthesis of protein responsible for binding $\mathrm{Ca}^{2+}$ ions in the cells of intestinal mucous membrane. It should be supposed that by the $42^{\text {nd }}$ day the chickens had not accumulated enough $\mathrm{Cu}$ to stimulate the synthesis of $1.25-(\mathrm{OH})_{2} \mathrm{D}_{3}$. Additionally, a drop in the concentration of Ca could be related to the dynamics of the development of the skeletal system in maturing birds, which requires a high intake of Ca from blood, and Cu ions favour the process of bone mineralization. On the other hand, a lower level of Fe in plasma observed under the influence of adding Cu-Gly may suggest that this element is better utilized in the process of heme synthesis.

Changes in the content of total cholesterol, its lipoprotein molecules of high and low density and TG, may suggest lipid transformations occurring in the body (Ganong 2005). Cholesterol released from endogenous and exogenous lipoproteins is esterified to $\mathrm{HDL}$, and its molecule participates in the reverse transportation to the liver. $\mathrm{HDL}$ concentration should account for more than $40 \%$ of total cholesterol so its reduction is unfavourable (Winnicka 2008).

The available literature provides little information about the effect of the use of Cu chelates on the content of cholesterol in the blood of broilers. It may be supposed that the organic compound of Cu affects lipid transformations in the animals' organisms. Previously published studies by Winiarska-Mieczan and Kwiecień (2015) indicated also that in the meat of chicken receiving $\mathrm{Cu}$ in the form of chelate the content of cholesterol was significantly $(p<0.05)$ lower compared to chicken receiving $\mathrm{Cu}$ in an organic form.

An addition of $\mathrm{Cu}$ in the form of Cu-Gly introduced into feeding stuffs, irrespective of the level applied, significantly contributed to a decrease in the level of total cholesterol, TG and LDL, as well as an increase in HDL, compared to the values of these parameters obtained with the use of their equivalents in the form of $\mathrm{CuSO}_{4}$. The observed reduction in the level of TG and total cholesterol may suggest a positive effect of the experimental agents applied. TG provide a cell with a source of energy which is released during their disintegration and during the oxidation of fatty acids. A reduced level of TG in the blood plasma of the birds is a positive phenomenon as it suggests a weakened process of lipogenesis in the liver and fat tissue, which seems to confirm "insulin-like" properties of copper. The content of the analyzed parameters may be conditioned by genetic factors, as well as by environmental agents, especially dietary ones, which may account for differences between the results of the author's own studies and those conducted by other authors. Ševčikova et al. (2003) observed the level of cholesterol being reduced by $24.9 \%$ with an addition of $\mathrm{Cu}$ in the form of glycine chelate, compared to the control group which was not administered an addition of Cu. Similarly, Aksu et al. (2010) noted a drop in the level of total cholesterol and the LDL fraction in the plasma of chickens fed with mixtures supplemented with $\mathrm{Zn}, \mathrm{Cu}$ and $\mathrm{Mn}$ in an organic form corresponding to $2 / 3$ of the requirement ( $26 \mathrm{mg}$ of $\mathrm{Zn}, 5 \mathrm{mg}$ of $\mathrm{Cu}, 40 \mathrm{mg}$ of $\mathrm{Mn}$ ) or with recommended doses ( $40 \mathrm{mg}$ of $\mathrm{Zn}, 8 \mathrm{mg}$ of $\mathrm{Cu}, 60 \mathrm{mg}$ of $\mathrm{Mn}$ ), along with an increased amount of HDL. Mondal et al. (2007) recorded a reduction in cholesterol in chickens' blood when $200 \mathrm{mg} \cdot \mathrm{kg}^{-1}$ of $\mathrm{Cu}$ in the form of protein was added to the mixture. Similar observations were made by Makarski and Zadura (2006) studying the influence of different doses of Cu 
on the level of lipid fractions in plasma. The lowest amount of cholesterol in chickens' plasma was demonstrated when $50 \mathrm{mg} \cdot \mathrm{dm}^{-3}$ of $\mathrm{Cu}$ and lysine chelate were added to water, along with a limited level of TG. Also, Chowdhury et al. (2004) noted that an increased level of $\mathrm{Cu}$ and methionine chelate (100 mg and $\left.150 \mathrm{mg} \cdot \mathrm{kg}^{-1}\right)$ was accompanied by a lower level of TG in the plasma. This is a linear effect of $\mathrm{Cu}$ and fat accumulating in the liver. Conversely, Dmoch and Polonis (2007) using $30 \mathrm{mg} \cdot \mathrm{dm}^{-3} \mathrm{Cu}$ and lysine chelate with water in chickens' nutrition noted a significant increase in the level of cholesterol and TG concentration in the blood. Studies by Güçlü et al. (2008) demonstrated an elevated concentration of total cholesterol with an addition of 300 to $400 \mathrm{mg}$ of $\mathrm{Cu} / \mathrm{kg}$ in the form of Cu protein, while an addition of $450 \mathrm{mg} \cdot \mathrm{kg}^{-1}$ resulted in a higher level of HDL. Konjufca et al. (1997) report that an addition of $\mathrm{Cu}$ in an organic form to feed leads to a higher content of cholesterol and the HDL fraction, while LDL is reduced. However, Lee et al. (2001) do not confirm these results.

The activity of ALP, ALT, AST and LDH enzymes, irrespective of the amount of organic Cu, did not differ from reference values (Winnicka 2008). An addition of a premix in the form of Cu-Gly to mixtures for Ross 308 chickens significantly enhanced the activity of ALT, AST and LDH in chickens' blood compared to the activity of these enzymes when inorganic $\mathrm{Cu}$ is applied. An increased concentration of LDH in blood may suggest damage to internal organs, such as pathological changes in the birds' livers. For this particular reason, after slaughter the chickens were subjected to a detailed anatomopathological analysis which did not reveal any changes in these organs, and the level of LDL determined in the author's own studies did not exceed physiological norms. It may thus be concluded that the increase in LDH activity was caused just by intensified glycogenesis processes. The activity of this enzyme may reveal great diversity, depending on the birds' age (Szabó et al. 2005). Similarly, in studies by Makarski et al. (2009a) the use of lysine-and-copper chelate amounting to $50 \mathrm{mg} \cdot \mathrm{dm}^{-3}$ resulted in a higher activity of ALT, AST and LDG in the blood of male turkeys, which seems to confirm the intensification of endogenous amino acids necessary to synthesize proteins. The studies by Güçlü et al. (2008) showed that an addition of 450 $\mathrm{mg} \cdot \mathrm{kg}^{-1}$ of Cu resulted in higher activity of ALP and lower activity of ALT and LDH in laying hens.

\section{The hematological parameters of blood}

An important source of information on the health status of an animal is the concentration of haemoglobin and the value of haematocrit. The values of the blood's haematological indices were within reference values (Winnicka 2008). An addition of organic Cu led to a significant increase in the number of white blood cells and the haematocrit value. Haemoglobin biosynthesis is directly related to two elements, namely Fe and Cu, because Cu present in ceruloplasmin regulates the transport and metabolism of iron. The lowest concentration of haemoglobin was observed for mixtures supplemented with Cu limited to $50 \%$, in the form of $\mathrm{CuSO}_{4}$. On the other hand, the highest number of red blood cells was recorded when the chickens' diet was supplemented with copper in amounts fully satisfying the requirement. Copper has a stimulating effect on weight gain in chickens due to its participation in the process of haemoglobin synthesis. The increase in haematological parameters, noted in the study, may result from a lower concentration of Fe in the plasma, which suggests it is better utilized in the process of heme synthesis. Improved haematological indicators were observed in studies by Makarski et al. (2002), following an addition of $\mathrm{Cu}$ in the form of $\mathrm{Cu}$-lysine chelate and $\mathrm{Cu}$-methionine chelate. Later studies performed by Makarski and Zadura (2006) showed that supplementing turkeys' diet with Cu-lysine chelate did not significantly affect the level of haematological indices of blood.

\section{Conclusion}

Summing up the obtained results, it may be concluded that adding lower levels of $\mathrm{Cu}\left(8 \mathrm{and} 4 \mathrm{mg} \cdot \mathrm{kg}^{-1}\right)$ in comparison with recommended doses $\left(16 \mathrm{mg} \cdot \mathrm{kg}^{-1}\right)$ to the mixtures for broiler chickens, in the form of highly assimilable organic sources did not reduce the content of minerals in the chickens' livers. The biochemical and haematological parameters of the chickens' blood, which are among the indicators defining the birds' health status, remained within the range of physiological norms when the analyzed elements were added at lower levels. Adding $\mathrm{Cu}$ at lower levels is also supported by ecological aspects since such levels are more environmentally friendly (reduced excretion of $\mathrm{Cu}, \mathrm{Zn}$ and Fe with droppings). The results indicate that the use of organic $\mathrm{Cu}$ did not decrease the examined parameters and since they are better assimilable in comparison to $\mathrm{CuSO}_{4}$, they must be taken into account when preparing feed mixture recipes for chickens. 
M. Kwiecień et al. (2015) 24: 92-103

\section{Acknowledgements}

This work, project NN 311543540, was financially supported by the Ministry of Science and Higher Education, Poland. The authors wish to thank ARKOP Sp. z o.o. (Bukowno, Poland) for providing the necessary organically complexed copper (GLYSTAR FORTE Cu) used for the purposes of this experiment.

\section{References}

Aksu, D.S., Aksu, T. \& Őzsoy, B. 2010. The effects of lower supplementation levels of organically complexed minerals (zinc, copper and manganese) versus inorganic forms on hematological and biochemical parameters in broilers. Kafkas Universitesi Veteriner Fakultesi Dergisi 16: 553-559.

AOAC 2000. Official Methods of Analysis. Horwitz W. (ed.). 17th ed. AOAC International, Gaithersburg, MD, USA.

Arias, V.J. \& Koutsos, E.A. 2006. Effects of copper source and level in intestinal physiology and growth of broiler chickens. Poultry Science 85: 999-1007.

Arredondo, M. \& Nunez, M.T. 2005. Iron and copper metabolism. Molecular Aspects of Medicine 26: 313-327.

Aviagen, 2013. Ross 308 parent stock: Nutrition specification. en.aviagen.com.

Aydin, A., Pekel, A.Y., Issa, G., Demirel, G. \& Patterson, P.H. 2010. Effects of dietary copper, citric acid, and microbial phytase on digesta $\mathrm{pH}$ and ileal and carcass microbiota of broiler chickens fed a low available phosphorus diet. Journal of Applied Poultry Research 19: 422-431.

Banks, K.M., Thompson, K.L., Rush, J.K. \& Applegate, T.J. 2004. Effects of copper source on phosphorus retention in broiler chicks and laying hens. Poultry Science 83: 990-996.

Bao, Y.M., Choct, M., lji, P.A. \& Bruerton, K. 2007. Effect of organically complexed copper, iron, manganese, and zinc on broiler performance, mineral excretion, and accumulation in tissues. The Journal of Applied Poultry Research 16: 448-455.

Chowdhury, S.D., Paik, I.K., Namkung, H. \& Lim, H.S. 2004. Responses of broiler chickens to organic copper fed in the form of copper-methionine chelate. Animal Feed Science and Technology 115: 281-293.

Dmoch, M. \& Polonis, A. 2007. Influence of biopleks-Cu on hematological and biochemical indices and content of mineral components in blood of chicken broilers. Zootechnica - Acta Scientarum Polonorum 6: 11-18.

Dobrzański, Z., Korczyński, M., Chojnacka, K., Górecki, H. \& Opaliński, S. 2008. Influence of organic forms of copper, manganese and iron on bioaccumulation of these metals and zinc in laying hens. Journal of Elementology 13: 309-319.

Dozier, W.A., Davis, A.J., Freeman, M.E. \& Ward, T.L. 2003. Early growth and environmental implications of dietary zinc and copper concentrations and sources of broiler chicks. British Poultry Science 44: 726-731.

EC 2009. Council Regulation (EC) No 1099/2009 of 24 September 2009 on the protection of animals at the time of killing. The Official Journal of the European Union L 303: 1-30.

Ettle, T., Schlegel, P. \& Roth, X. 2008. Investigations on iron bioavailability of different sources and supply levels in piglets. Journal of Animal Physiology and Animal Nutrition 92: 30-45.

Feng, J., Ma, W.Q., Xu, Z.R., Heb, J.X., Wang, Y.Z. \& Liu J.X. 2009. The effect of iron glycine chelate on tissue mineral levels, fecal mineral concentration, and liver antioxidant enzyme activity in weanling pigs. Animal Feed Science and Technology 150: 106-113.

Feng, J., Maa, W.Q., Xua, Z.R., Wang, Y.Z. \& Liu, J.X. 2007. Effects of iron glycine chelate on growth, haematological and immunological characteristics in weanling pigs. Animal Feed Science and Technology 134: 261-272.

Friedewald, W.T., Levy, R.I. \& Frederickson, D.S. 1972. Estimation of the concentration of low-density lipoprotein cholesterol in plasma, without use of the preparative ultracentrifuge. Clinical Chemistry 18: 499-502.

Ganong, W. 2005. Reviev of Medical Physiology. $12^{\text {th }}$ ed. McGraw-Hill Medical, New York, USA. 928 p.

Güçlü, B.K., Kara, K., Beyaz, L., Uyanik, F., Eren, M. \& Atasever, A. 2008. Influence of dietary copper proteinate on performance, selected biochemical parameters, lipid peroxidation, liver, and egg copper content in laying hens. Biological Trace Element Research 125: 160-169.

Konjufca, V.H., Pesti, G.M. \& Bakalli, R.I. 1997. Modulation of cholesterol levels in broiler meat by dietary garlic and copper. Poultry Science 76: 1264-1274.

Kwiecień, M., Winiarska-Mieczan, A., Zawiślak, K. \& Sroka, S. 2014. Effect of copper glycinate chelate on biomechanical, morphometric and chemical properties of chicken femur. Annals of Animal Science 14: 127-139.

Kwiecień, M., Smolińska, W. \& Bujanowicz-Haraś B. 2015. Effects of iron glycine chelate on growth, carcass characteristic, liver mineral concentrations and haematological and biochemical blood parameters in broilers. Journal of Animal Physiology and Animal Nutrition. DOI: 10.1111/jpn.12322.

Lee, S.H., Choi, S.C., Chae, B.J., Lee, J.K. \& Acda, S.P. 2001. Evaluation of metal-amino acid chelates and complexes at various levels of copper and zinc in weanling pigs and broiler chicks. Asian-Australasian Journal of Animal Sciences 14: 1734-1740.

Luo, X.G., JI, F., Lin, Y.X., Steward, F.A., Lu, L., Liu, B. \& Yu, S.X. 2005. Effects of dietary supplementation with copper sulfate or tribasic copper chloride on broiler performance, relative copper bioavailability, and oxidation stability of vitamin E in feed. Poultry Science 84: 888-893.

Makarski, B. 2002. Wpływ kompleksu chelatowego miedzi z lizyną oraz fitazy na reakcje biologiczne indyków. Rozprawy Naukowe AR Lublin. 256. (in Polish).

Makarski, B., Kwiecień, M. \& Zadura, A. 2009a. The influence of copper in the form of a lysine chelate and lactic acid on biological reactions of turkeys. I. Hematological and biochemical indices of blood and production effects of turkeys. In: Pasternak K. (ed.) Elements, the environment and human life. p. 184-192. (Monographs, in English) 
M. Kwiecień et al. (2015) 24: 92-103

Makarski, B., Kwiecień, M. \& Zadura, A. 2009b. The influence of copper in the form of a lysine chelate and lactic acid on biological reactions of turkeys. II: The shares of mineral elements in the tissues and the contents of the large intestine in turkeys. In: Pasternak K. (ed.) Elements, the environment and human life. p. 193-198. (Monographs, in English)

Makarski, B., Polonis, A., Czech, A. \& Sembratowicz, I. 2002. Effect of copper deriving from inorganic form and chelats on the components of blood and performance of turkeys. Annales Universitatis Mariae Curie-Skłodowska (sectio EE) 41: 287-293.

Makarski, B. \& Zadura, A. 2006. Influence of copper and lysine chelate on hematological and biochemical component levels in turkey blood. Annales Universitatis Mariae Curie-Skłodowska (sectio EE) 48: 357-363.

Makarski, B., Zadura, A. \& Kwiecień, M. 2006. The effect of Cu-Lysine chelate in turkeys diets on the results of slaughter analysis, chemical composition and the fatty acids profile in tissues. Zootechnica - Acta Scientarum Polonorum 5: 57-66.

Männer, K., Simon, O. \& Schlegel, P. 2006. Effects of different iron, manganese, zinc and copper sources (sulphates, chelates, glycinates) on their bioavailability in early weaned piglets. In: Rodehutscord, M. (ed.) 9. Tagung Schweine- und Geflügelernährung. Institut für Agrar- und Ernährungswissenschaften, Universität Halle-Wittenberg, Deutschland. p. 25-27.

Mondal, M.K., Das, T.K., Biswas, P., Samanta, C.C. \& Bairagy, B. 2007. Influence of dietary inorganic and organic copper salt and level of soybean oil on plasma lipids, metabolites and mineral balance of broiler chickens. Animal Feed Science and Technology 139: 212-233.

Nollet L., Wakeman, W. \& Belyavin, C. 2005. Replacement of inorganic Cu, Mn, Fe and Zn with Bioplex on growth performance and faecal mineral excretion in broilers. Proceedings of the 15th European Symposium on poultry nutrition, Balatonfüred, Hungary. p. 183-185.

Nollet, L., van der Klis, J.D., Lensing, M. \& Spring, P. 2007. The effect of replacing inorganic with organic trace minerals in broiler diets on productive performance and mineral excretion. The Journal of Applied Poultry Research 16: 592-597.

Nollet, L., Huyghebaert, G., \& Spring, P. 2008. Effect of different levels of dietary organic (bioplex) trace minerals on live performance of broiler chickens by growth phases. The Journal of Applied Poultry Research 17: 109-115.

NRC 1994. National Research Council. Nutrient Requirements of Poultry. $9^{\text {th }}$ rev. ed. National Academy Press, Washington, USA. 176 p. Nys, Y. 2001. Trace elements as related to growth and health in chickens. Productions Animales 14: 171-180.

Pierce, J.L., Pescatore, A.J., Ford, M.J. \& Cantor, A.H. 2005. The effects of source and level of dietary copper on copper and zinc metabolism in broiler chicks. Alltech-University of Kentucky Nutrition Research Alliance. Lexington, Abstracts M 30, 10.

PN-76/R-64781, 1976. Polska Norma. Pasze. Oznaczenie zawartości fosforu. (in Polish).

Predieri, G., Elviri L., Tegoni, M., Zagnoni, I., Cinti, E., Biagi, G., Ferruzza, S. \& Leonardi, G. 2005. Metal chelates of 2-hydroxy-4-methylthiobutanoic acid in animal feeding. Part 2: Further characterizations, in vitro and in vivo investigations. Journal of Inorganic Biochemistry 99: 627-636.

Reeves, P.G. \& DeMars, L.C.S. 2004. Copper deficiency reduces iron absorption and biological half-life in male rats. Journal of Nutrition 134: 1953-1957.

Ruiz, J.A., Pérez-Vendrell, A.M., \& Esteve-Garcia, E. 2000. Effect of dietary iron and copper on performance and oxidative stability in broiler leg meat. British Poultry Science 41: 163-167.

Ševčíková, S., Skřivan, M., Skřivanová, V., Tůmová, E. \& Koucký, M. 2003. Effect of supplementation of copper in copper sulphate and $\mathrm{Cu}$-glycine on fatty acid profile in meat of broiler chickens, cholesterol content and oxidation stability of fat. Czech Journal of Animal Science 48: 432-440.

Shelton, J.L. \& Southern, L.L. 2006. Effects of phytase addition with or without a trace mineral premix on growth performance, bone response variables, and tissue mineral concentration in commercial broilers. The Journal of Applied Poultry Research 15: 94-102. StatSoft Inc. 1997. Statistica for Windows. Tulsa: StatSoft.

Świątkiewicz, S., Koreleski, J. \& Zhong, D.Q. 2001. The bioavailability of zinc from inorganic and organic sources in broiler chickens as affected by addition of phytase. Journal of Animal Feed Sciences 10: 317-328.

Szabó, A., Mézes, M., Horn, P., Sütö, Z., Bázár, G.Y. \& Romvári, R. 2005: Developmental dynamice of some blond biochemical parameters in growing turkey (Meleagris Gallopavo). Acta Veterinaria Hungarica 53: 397-409.

Vieira, S.L. 2008. Chelated minerals for poultry. Revista Brasileira de Ciência Avícola 10: 73-79.

Waldroup, P.W., Kersey, J.H., Saleh, E.A., Fritts, C.A., Yan, F., Stilborn, H.L., Crum Jr., R.C. \& Raboy, V. 2000. Nonphytate phosphorus requirement and phosphorus excretion of broilers fed diets composed of normal or high available phosphate corn with and without microbial phytase. Poultry Science 79:1451-1459.

Wang, Z., Cerrate, S., Coto, C., Yan, F. \& Waldroup, P.W. 2007. Evaluation of MINTREX ${ }^{\circledR}$ copper as a source of copper in broiler diets. International Journal of Poultry Sciences 6: 308-313.

Winiarska-Mieczan, A. \& Kwiecień M. 2015. The effects of copper-glycine complexes on chemical composition and sensory attributes of raw, cooked and grilled chicken meat. Journal of Food Science and Technology DOI 10.1007/s13197-014-1510-8.

Winnicka, A. 2008. Wartości referencyjne podstawowych badań laboratoryjnych w weterynarii. SGGW, Warszawa. 122 p. (In Polish).

Xia, M.S., Hu, C.H. \& Xu, Z.R. 2004. Effects of copper-bearing montmorillonite on growth performance, digestive enzyme activities, and intestinal microflora and morphology of male broilers. Poultry Science 83:1868-1875.

Žilic, S.M., Božovic, I.N., Savic, S. \& Šobajic, S. 2006. Heat processing of soybean kernel and its effect on lysine availability and protein solubility. Central European Journal of Biology 1: 572-583.

Ziołecki, J. \& Doruchowski, W. 1989. Metoda oceny wartości rzeźnej drobiu. COBRD, Poznań. p. 1-22. (in Polish). 